\title{
Ligation of the Common Bile Duct in the Fetal Lamb: an Experimental Model for the Study of Biliary Atresia
}

\author{
LEWIS SPITZ \\ Department of Pediatric Surgery, The Children's Hospital. Sheffield, England
}

\begin{abstract}
Summary
Intrauterine ligation of the common bile duct was carried out in ten fetal lambs at approximately 80 days gestational age. Six of the fetal lambs survived until term and were sacrificed at varying periods until the 36th day of life. The lesion which developed resembled a "correctable" type of extrahepatic biliary atresia [Kasai type I (b)]. The lining epithelium was either totally or incompletely denuded in the blind end of the common duct proximal to the obstruction.
\end{abstract}

\section{Speculation}

The compliance of the wall of the common bile duct would appear to vary with the age at which an obstruction is introduced. The finding of an incomplete epithelial lining in the blind bulbous end of the proximal common duct may be of practical importance in influencing the siting of a biliary-intestinal anastomosis in the operative correction of the clinical condition. The failure to achieve mucosa-to-mucosa apposition may predispose towards anastomotic stenosis with all its sequelae. The findings in this small preliminary study are of sufficient interest to warrant further investigation.

\section{INTRODUCTION}

The etiology and pathogenesis of biliary atresia remains obscure despite numerous etiologic hypotheses and a wide variety of unsuccessful attempts to produce the condition in the experimental animal. Basically, the theories which have been proposed can be divided into three categories.

\section{EMBRYOLOGICAL DEFECT $(29,38)$}

Embryological defect is the failure of recanalization of the solid stage of development of the extrahepatic ducts. Evidence to refute this theory includes the rarity with which the condition has been found in the newborn infant (18) and at necropsy of stillborns (5), the fact that the onset of jaundice is delayed for 2 to $3 \mathrm{wk}$ in most cases $(16,22,36)$, and the finding of atresia in a system previously shown to be patent $(8,12,26)$.

\section{GENETIC DEFECT}

Although biliary atresia has been documented in two $(17,23$, $37)$ and even three $(14,28,35)$ siblings in the same family, Danks and Bodian (9) categorically state that there is no evidence for a familial tendency in this disease. The condition is said to be more common in the Japanese (3), but this has been contested by Shim et al. (31).

$$
\text { VIRAL ETIOLOGY (4, 7, 10, 11, 24, 27, 34) }
$$

The basic pathology is reputed to be a sclerosing type inflammatory reaction of viral origin which produces varying degrees of damage to the liver cell and biliary duct epithelium. The end result of the inflammatory process may be either neonatal hepatitis when hepatocyte damage is predominant or extrahepatic biliary atresia when the epithelium has been most severely damaged.

Attempts to produce extrahepatic biliary atresia in the experimental animal have for the most part been unsuccessful. Experimental procedures which have been reported include hepatic artery ligation in a variety of fetal animals, e.g., rabbit (21), lamb (25), and pig (1); ligation of the common duct in the pig (30): and a combination of ligation with or without sclerosant injection in the puppy (13). Only Pickett and Briggs (25) were able to produce anything resembling extrahepatic biliary atresia. This was achieved by interruption of the blood supply to the common duct in the fetal lamb.

Ligation of the common bile duct in the newborn lamb has been shown to result in choledochal cyst formation (32). This

FOETAL LIGATION OF COMMON BILE DUCT

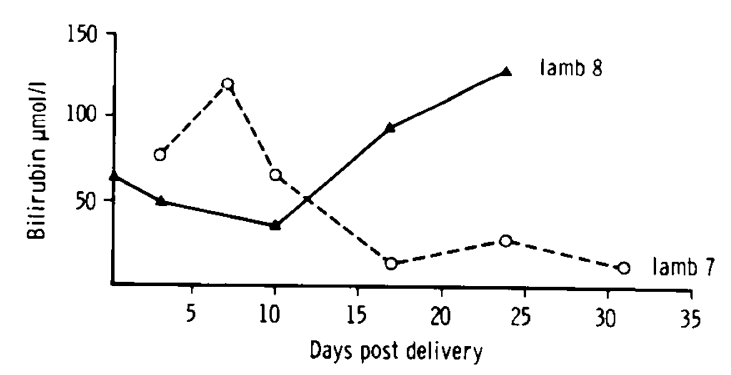

Fig. 1. Serial serum bilirubin levels ( $\mu \mathrm{mol} / \mathrm{liter})$ in Lambs 7 and 8 .

Table 1. Caliber of extrahepatic biliary system following intrauterine ligation of common duct

\begin{tabular}{|c|c|c|c|c|}
\hline \multirow[b]{2}{*}{ Lamb } & \multirow{2}{*}{$\begin{array}{c}\text { Duration of } \\
\text { extrauterine } \\
\text { survival } \\
\text { (days) }\end{array}$} & \multirow{2}{*}{$\begin{array}{c}\text { Total } \\
\text { survival } \\
\text { time } \\
\text { (days) }\end{array}$} & \multicolumn{2}{|c|}{$\begin{array}{c}\text { Maximum external } \\
\text { diameter }(\mathrm{mm})\end{array}$} \\
\hline & & & $\begin{array}{c}\text { Common } \\
\text { duct }\end{array}$ & $\begin{array}{c}\text { Gall } \\
\text { bladder }\end{array}$ \\
\hline 2 & 0 & 75 & 5 & 7 \\
\hline 4 & 0 & 80 & 7 & 4 \\
\hline 7 & 36 & 99 & 10 & 12.5 \\
\hline 8 & 24 & 89 & 13 & 8 \\
\hline 9 & 11 & 71 & 8 & 17 \\
\hline 10 & 13 & 88 & 10 & 14 \\
\hline
\end{tabular}


report examines the effect of biliary obstruction in the developing fetal lamb in utero.

\section{MATERIALS AND METHODS}

The experimental material consisted of ten pregnant ewes operated upon at approximately 80 days of gestation (average gestation, 155 days). The ewes were allowed access to water only for
$24 \mathrm{hr}$ preoperatively, and the operation was performed under general endotracheal anesthesia. Anesthesia was induced by IV pentothal sodium and was maintained by nitrous oxide, halothane, and oxygen.

\section{OPERATIVE PROCEDURE}

Using a sterile technique, the peritoneal cavity of the ewe was entered by means of a lower abdominal midline incision. The
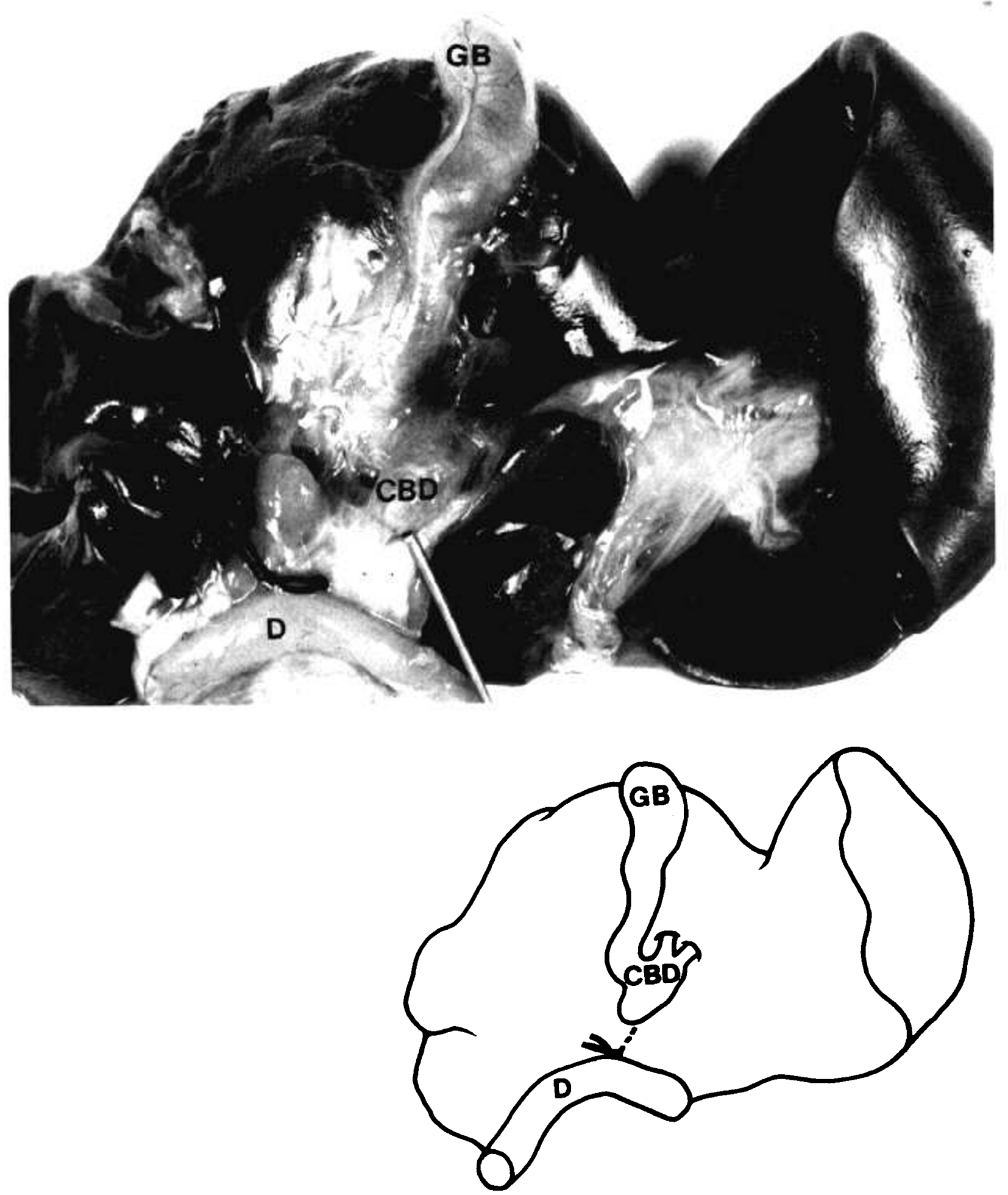

Fig. 2. Macroscopic appearance of the liver and extrahepatic biliary system in Lamb 2 sacrificed on the first day of life. Total survival was 75 days. Inset, liver and biliary system diagrammatically. $G B$, gall bladder; $C B D$, common duct; $D$, duodenum. The wall of the common duct has maintained its parallelism and cannot be classified as cystic dilatation. 
appropriate horn of the bicornuate uterus containing the fetal lamb was delivered into the incision and covered in warm moist swabs. An area in the proximal uterus between the placental cotyledons was selected for the uterine incision which was made with electrocautery to limit blood loss. The edges of the incision were grasped with tissue forceps and held vertical throughout the operative procedure to limit the loss of amniotic fluid. The fetal lamb was delivered out of the uterine cavity and gently placed on warm moist swabs, taking particular care not to interfere with umbilical circulation.

Table 2. Histopathological findings in the liver in lambs which had undergone intrauterine common duct ligation

\begin{tabular}{|c|c|c|c|c|c|}
\hline Lamb & $\begin{array}{c}\text { Bile } \\
\text { plugs } \\
\text { and } \\
\text { thrombi }\end{array}$ & $\begin{array}{l}\text { Prolif- } \\
\text { erating } \\
\text { bile } \\
\text { ductules } \\
\text { in } \\
\text { portal } \\
\text { tracts }\end{array}$ & $\begin{array}{c}\text { Bile } \\
\text { lakes }\end{array}$ & $\begin{array}{c}\text { Portal } \\
\text { tracts } \\
\text { enlarged } \\
\text { and } \\
\text { edematous }\end{array}$ & $\begin{array}{c}\text { Periporta } \\
\text { fibrosis }\end{array}$ \\
\hline 2 & ++ & + & - & + & + \\
\hline 4 & ++ & + & - & + & \pm \\
\hline 7 & ++ & + & - & + & +++ \\
\hline 8 & ++ & - & + & - & + \\
\hline 9 & ++ & - & + & + & ++ \\
\hline 10 & ++ & - & + & + & ++ \\
\hline
\end{tabular}

FETAL PROCEDURE

The abdomen was opened via a right transverse muscle-cutting incision using diathermy. The relatively large liver of the fetus was gently retracted cranially, and the intestines, including the stomach and duodenum, were displaced caudally. (Meticulous care is imperative during these manipulations because the tissues are extremely friable). The common bile duct of the fetus was identified within the gastrohepatic omentum, and a single 5.0 atraumatic silk ligature was secured around the lower portion of the duct. The common duct itself was not dissected free from its surrounding structures, nor was it traumatized in any way other than that involved in placing the ligature in position. The abdominal wall of the fetus was closed in one layer with a continuous silk suture including all layers.

The fetal lamb was returned into the uterine cavity within the amniotic membrane. The uterine incision was closed in three separate layers. The maternal abdomen was closed in layers.

\section{POSTOPERATIVE MANAGEMENT}

Perioperatively, the ewes received an IM injection of 2 megaunits of benzathine penicillin and $1 \mathrm{~g}$ of streptomycin. These antibiotics were continued postoperatively for 5 days. No other drugs were administered during the postoperative period. The gestation was allowed to continue to term.

\section{RESULTS}

One ewe died during the operation, and three aborted between the second and fourteenth postoperative days due to technical or infective complications. The remaining six ewes carried the pregnancy through to term and were delivered of healthy lambs. Two of these lambs were sacrificed on the day of birth, two died

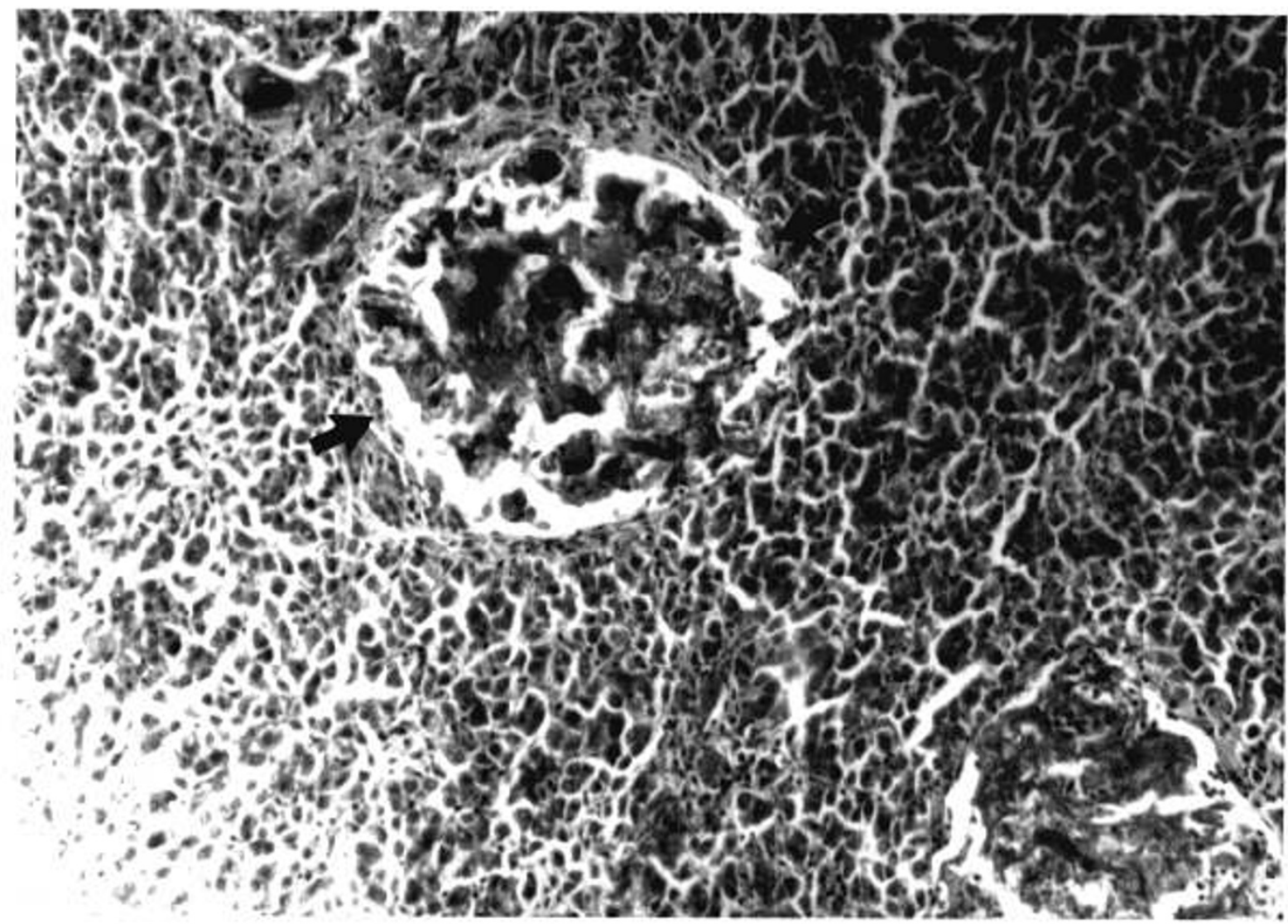

Fig. 3. Microscopic features of the liver in Lamb 10 showing the presence of bile lakes within the lobular tissue. $\times 130$. 
unexpectedly on the 12th and 36th days of life, and the remaining two were sacrificed because they were ill and listless on the 11th and 24th days, respectively. A necropsy was performed immediately after death or sacrifice. The liver, biliary system, and duodenum was removed en bloc and fixed in a $10 \%$ formaldehyde solution. Measurements were made of the greatest external diameter of the gall bladder and the common bile duct proximal to the ligature. Tissue from the liver and serial sections of the extrahepatic biliary system from the porta hepatis to the duodenum were removed, embedded in a standard paraffin wax technique, cut at $0.6 \mu \mathrm{m}$, and stained with haematoxylin and eosin and Masson's trichrome. Cholangiography was not performed because the delay in fixation of tissue may have resulted in epithelial necrosis and therefore negated the histologic findings.

\section{FINDINGS}

All the animals were biochemically jaundiced at or within a few days of birth. After a slight initial rise in bilirubin level in Lamb 7 , there followed a progressive and sustained fall in bilirubin levels to within normal levels. Conversely, Lamb 8 showed an initial fall followed by a progressive rise in bilirubin levels (Fig. 1). The effects of intrauterine obstruction of the common duct on the caliber of the gall bladder and common duct proximal to the ligature are shown in Table I. In three lambs (Lambs 2, 4, and 8), the gall bladder was collapsed and well below the expected size for the normal neonatal lamb $(17 \mathrm{~mm})$. In the remaining three lambs (Lambs 7, 9, and 10), the gall bladder was distended with bile, but its dimensions remained within the normal range. The bile duct proximal to the silk ligature was distended in all the lambs, the extent of dilatation ranging from 5 to $13 \mathrm{~mm}$ (mean, $8.8 \mathrm{~mm}$ ). (The normal common duct at this age measures $2 \mathrm{~mm}$ in diameter). Distal to the ligature, the common duct could be identified as a fine, narrow, collapsed structure extending towards the superior surface of the duodenum. The liver appeared mac- roscopically normal in size, appearance, and consistency in all six animals. The macroscopic features in Lamb 2 are shown in Figure

\section{MICROSCOPIC FINDINGS}

The Liver. Cholestasis, to a greater or lesser extent, was present in all the lambs. The histological findings are summarized in Table 2. Bile plugs in the Kupffer and liver cells and feathery degeneration of the hepatocytes were evident in all the animals. Proliferating bile ductules were evident in the portal tracts in three lambs, whereas bile lakes (Fig. 3) were present in the remaining three lambs. The greatest increase in periportal fibrous tissue occurred in the lamb surviving for the longest period (Fig. 4).

The Bile Ducts. Sections of the bile duct in each specimen were examined at the level of the porta hepatis, at the junction with the cystic duct, immediately proximal to the ligature, and at the duct distal to the ligature (Table 3). Postmortem autolysis of the surface epithelium was almost certainly responsible for the extensive degeneration in Lambs 7 and 10, and the findings in these two animals are of no significance. Three of the remaining four lambs had intact surface epithelium of the bile ducts in the portahepatis (Fig. 5), although in only one of these was the lining epithelium present in the dilated common duct immediately proximal to the obstructing ligature. the remaining three showed complete absence of surface epithelium in the blind end of the common duct (Fig. 6 ). The common duct distal to the ligature was collapsed and narrow, and in five of the six lambs, it contained normal surface epithelium and acini. Of particular interest were the microscopic findings in the distal common duct in Lamb 4 (Fig. 7). The narrow duct was composed mainly of fibrous tissue containing many acini lined with an intact epithelium. The lumen, however, was almost completely obliterated and was totally denuded of an epithelial lining. The appearances closely resemble that of the fibrous remnant in patients with an extrahepatic biliary atresia (20).

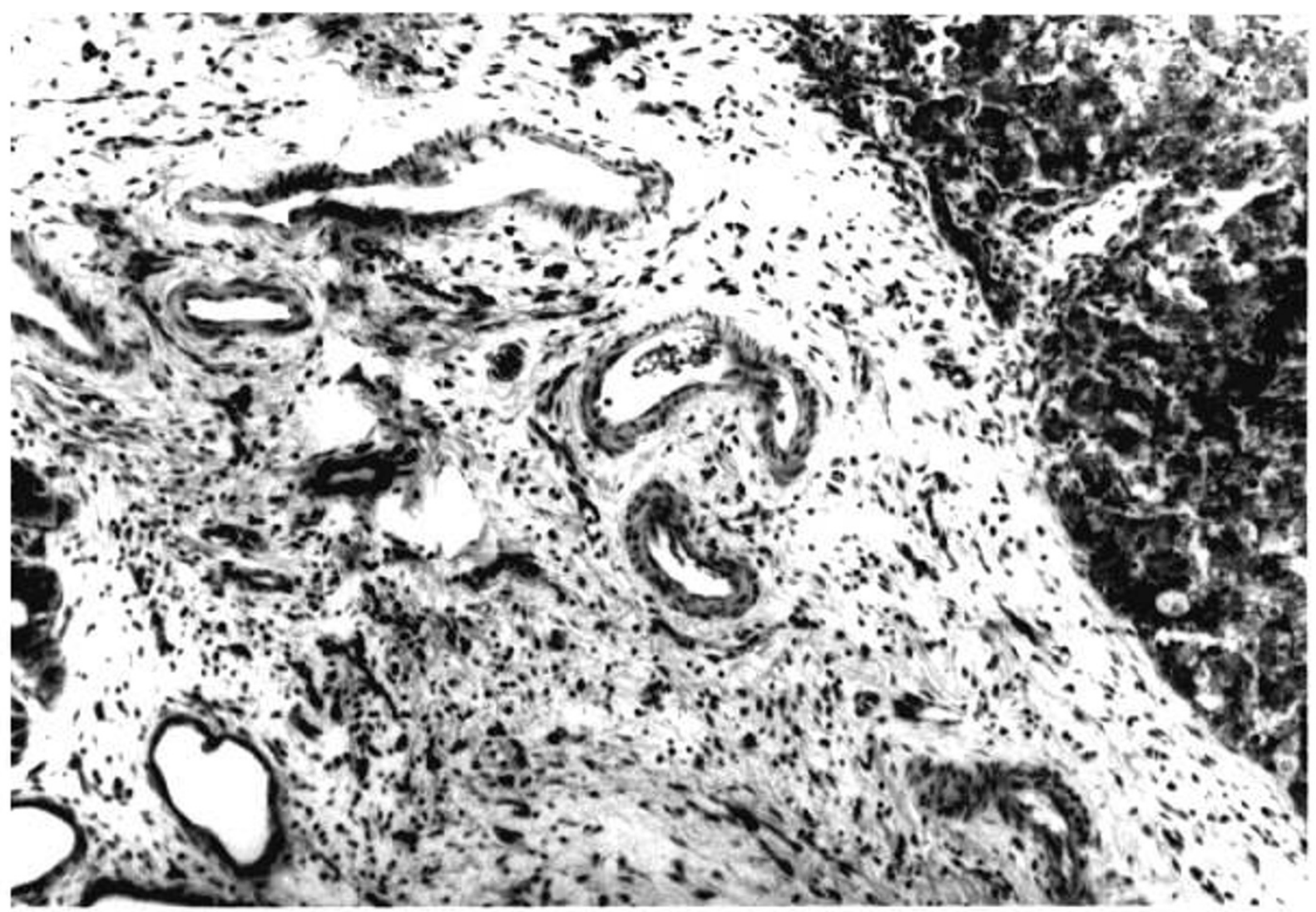

Fig. 4. Microscopic features of the liver in Lamb 7 showing proliferating bile ductules and increase in fibrous tissue in the portal tracts. $\times 130$ 
Table 3. Microscopic appearance of extrahepatic bile ducts in lambs surviving intrauterine ligation procedures

\begin{tabular}{|c|c|c|c|c|c|}
\hline $\begin{array}{l}\text { Level of duct } \\
\text { examined }\end{array}$ & Parameter & Lamb 2 & Lamb 4 & Lamb 8 & Lamb 9 \\
\hline \multirow[t]{2}{*}{ At porta hepatis } & Lining epithelium & $\begin{array}{l}\text { Intact cells severely } \\
\text { elongated }\end{array}$ & $\begin{array}{l}\text { Intact cells severely } \\
\text { elongated }\end{array}$ & Intact cells elongated & Denuded \\
\hline & Submucous glands & Present and normal & Present and normal & $\begin{array}{l}\text { Distended but normal cell } \\
\text { lining }\end{array}$ & Present but distended \\
\hline \multirow[t]{2}{*}{ At junction of cystic duct } & Lining epithelium & $\begin{array}{l}\text { Mostly denuded. } \\
\text { Few surviving islands }\end{array}$ & Partially denuded & Intact cells elongated & Completely absent \\
\hline & Submucous glands & Present and normal & Present and normal & $\begin{array}{l}\text { Acini distended but cells } \\
\text { normal }\end{array}$ & Acini scanty \\
\hline \multirow[t]{2}{*}{ Proximal to ligature } & Lining epithelium & Completely absent & Completely absent & $\begin{array}{l}\text { Intact cells severely elon- } \\
\text { gated }\end{array}$ & Completely denuded \\
\hline & Submucous glands & Present and normal & Present and normal & $\begin{array}{l}\text { Acini very dilated, lined } \\
\text { with elongated cells }\end{array}$ & Acini scanty \\
\hline \multirow{2}{*}{$\begin{array}{l}\text { Distal to ligature } \\
\text { (all small, narrow, collapsed } \\
\text { ducts }\end{array}$} & Lining epithelium & Normal and intact & $\begin{array}{l}\text { Small, slit-like lumen with- } \\
\text { out epithelial lining }\end{array}$ & Normal and intact & Normal and intact \\
\hline & Submucous glands & Present and normal & $\begin{array}{l}\text { Present and normal. Intense } \\
\text { inflammatory reaction in } \\
\text { wall }\end{array}$ & Present and normal & Present and normal \\
\hline
\end{tabular}




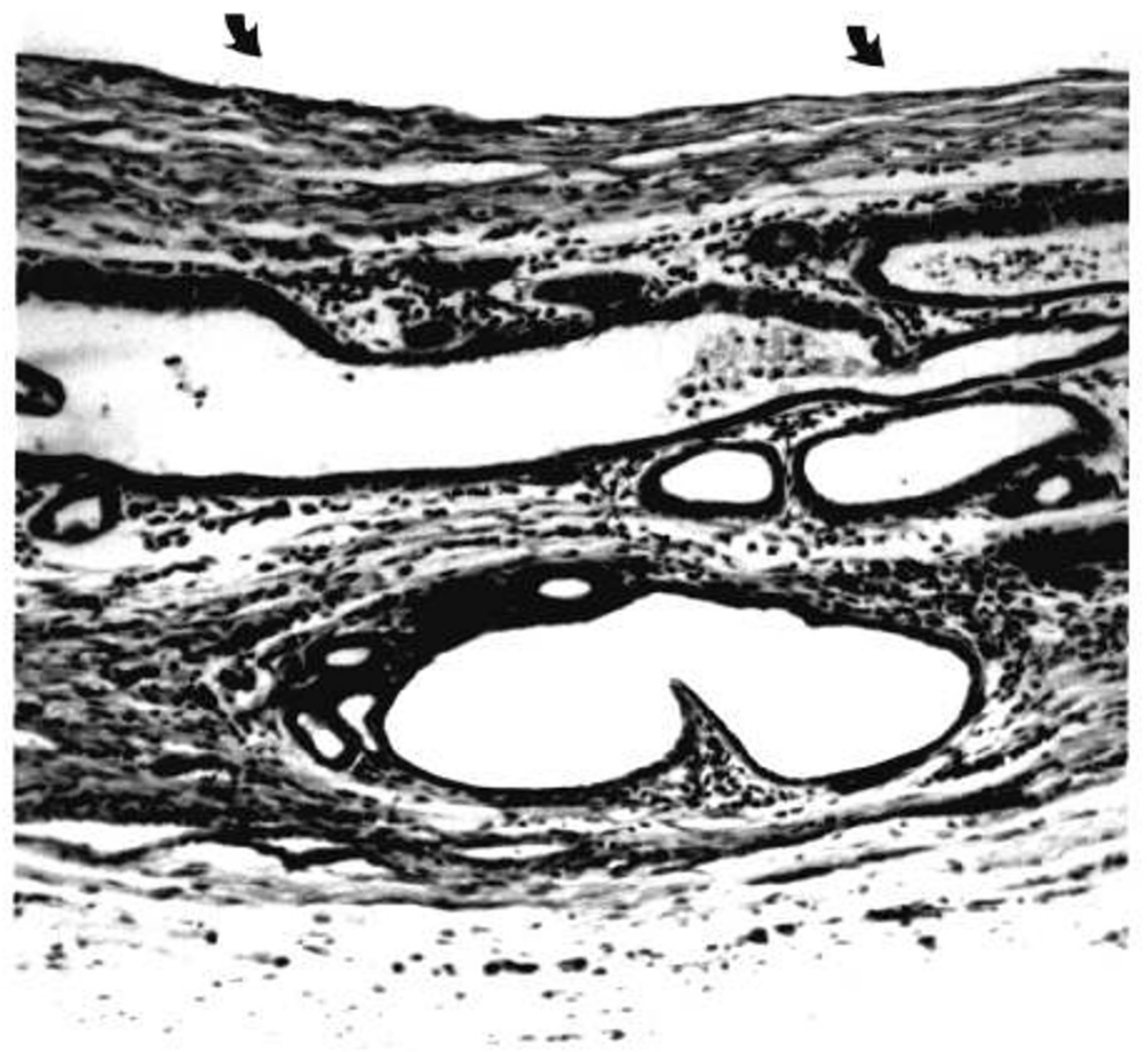

Fig. 5. Section of the wall of the common bile duct in the region of the porta hepatis (Lamb 8) showing dilated acini with lining cells elongated. The surface epithelium is present but stretched out and thin. $\times 130$.

\section{DISCUSSION}

Many experimental procedures have been devised in an attempt to produce biliary atresia in the laboratory animal. Morgan $e t$ al. (21) divided the hepatic artery in the fetal rabbit. Five of 14 surviving animals examined at varying periods after birth showed histologic evidence of "biliary atresia or hypoplasia" of the intrahepatic ductules. Holder and Ashcroft (13) subjected fetal puppies to either ligation of the common duct only, to injection of a sclerosant into the biliary tree, or to ligation and injection of sclerosant. Of thirty fetal pups which underwent these procedures. eight were subsequently born alive, and none was considered to have developed biliary atresia. Pickett and Briggs (25) ligated the hepatic artery in 11 fetal lambs. Seven of these lambs survived until term. Each was found to have an "interruption of the common duct adjacent to the tie which was found in each case medial to the common duct." They concluded that it was possible that biliary atresia may be the result of a vascular anomaly or catastrophe. Hepatic artery interruption in fetal and neonatal miniature pigs failed to produce an abnormality in the extrahepatic biliary tree in either group of animals. Schweizer (30) reporting on experiments on newborn domestic pigs concluded that simple ligation and division of the biliary tree was inadequate as an experiment. The bile duct had to be either totally destroyed. resulting in complete obliteration, or resected en bloc with the gall bladder to produce changes in the liver similar to that of extrahepatic biliary atresia.

The effect of ligation of the common bile duct in the sheep would appear to vary depending on the stage in the development of the animal at which the obstruction is introduced. In the newborn lamb, a choledochal cyst develops in all animals surviving in excess of four wk postoperatively (32). In the mature sheep, hydrops of the gall bladder with only moderate dilatation of the common duct is the most common effect of distal obstruction (33). The lesion which evolves after intrauterine ligation of the common duct has been shown to resemble that of an extrahepatic biliary 


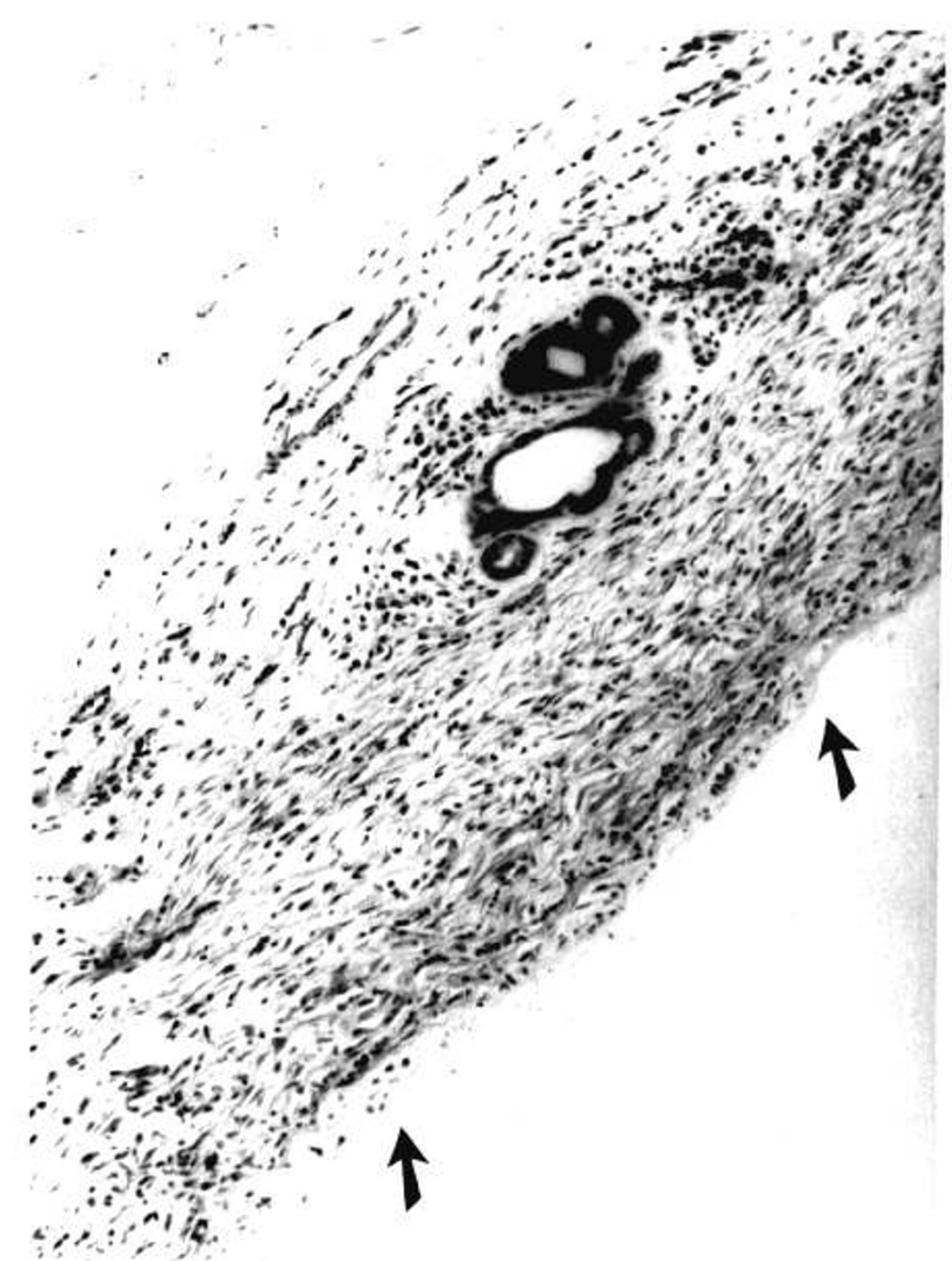

Fig. 6. Section of the wall of the dilated common bile duct immediately proximal to the obstruction, showing complete absence of epithelial lining but few surviving acini in duct wall (Lamb 9). $\times 130$. 


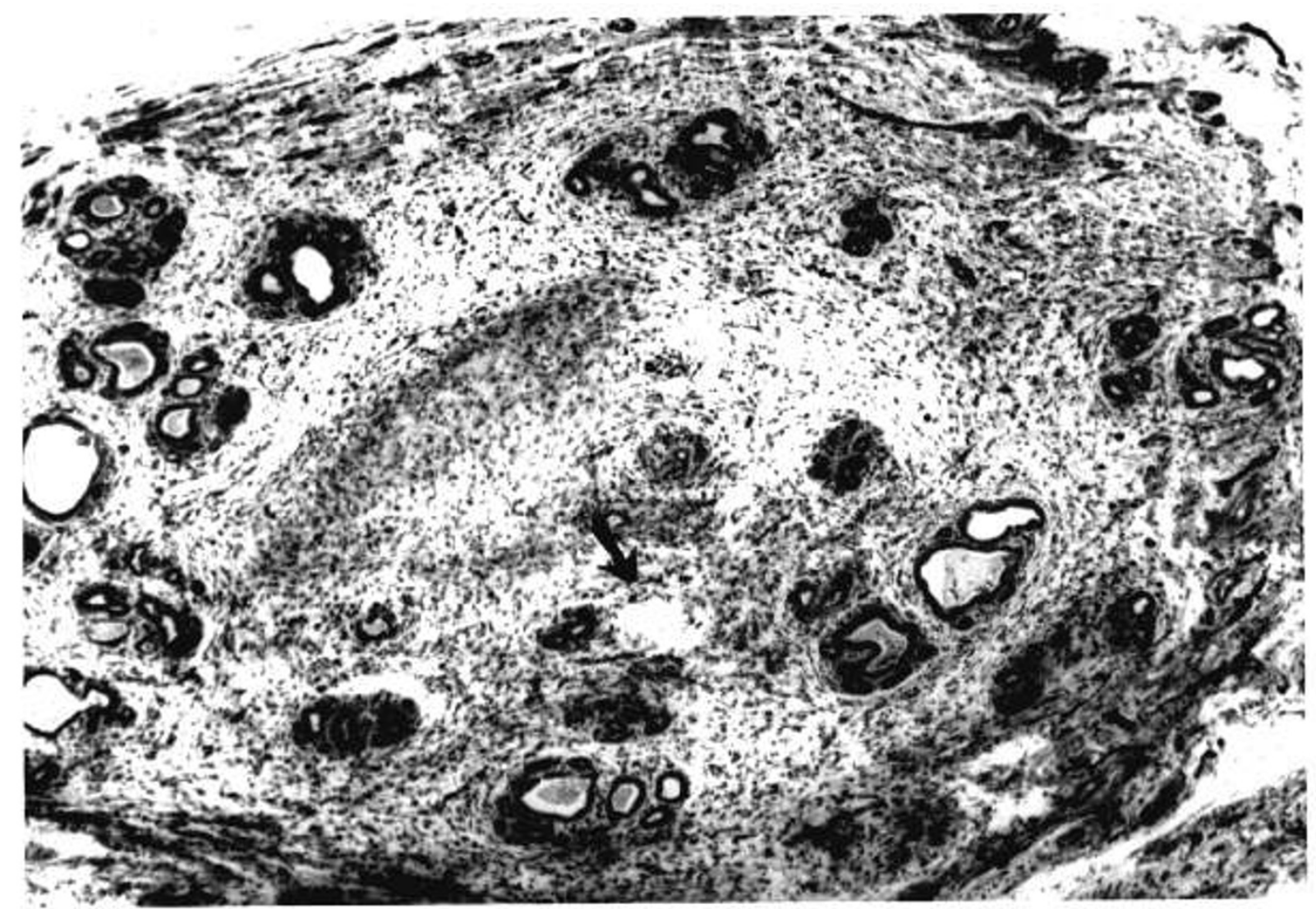

Fig. 7. Section of the common duct distal to the obstruction in Lamb 4 showing small, slit-like lumen without epithelial lining but numerous acini lined with intact epithelial cells. $\times 130$.

atresia of the "correctable" type, i.e., subtype I (b) of Kasai (15). No adequate explanation is forthcoming for the progressive and sustained fall in bilirubin levels in Lamb 7. An accessory bile duct could not be identified in this specimen, nor was there any evidence that recanalization of the duct had taken place. The failure of either the gall bladder or the extrahepatic bile ducts to dilate beyond modest proportions also defies a satisfactory explanation.

The finding of a deficient epithelial lining in the blind end of the common duct may be of practical importance in selecting the ideal site of the biliary intestinal anastomosis in the definitive treatment of an infant with a correctable-type biliary atresia. The failure to achieve a mucosa-to-mucosa apposition in a distally located by-pass procedure may predispose to stomal stenosis which may be responsible for the high incidence of postoperative complications such as ascending cholangitis, progressive biliary cirrhosis, and the generally poor long-term results experienced in infants with this anomaly $(2,6,19)$.

\section{REFERENCES AND NOTES}

1. Andrews, H. G., Shermeta, D. W., and White, J. J., and Halles, J. A., Jr.: Hepatic artery interruption in fetal and neonatal miniature pigs: studies in the pathogenesis of biliary atresia. Surg. Forum, 21: 384 (1970).

2. Arima, E., Fonkalsrud, E. W., and Neerhout, R. C.: Experiences in the management of surgically correctable biliary atresia. Surgery, 75 : 228 (1974).

3. Bill, A. H.: Editorial note: biliary atresia and choledochal cyst. New concepts of cause and treatment. Prog. Pediatr. Surg., 6: 62 (1974).

4. Bill, A. H., Brennan, W. S., and Huseby, T. L.: Biliary atresia. New concepts of pathology. diagnosis and management. Arch. Surg., 109: 367 (1974).

5. Brent, R. L.: Persistent jaundice in infancy. J. Pediatr., 61: 111 (1962).

6. Carcassonne. M., and Bensoussan, A.: Long-term results in treatment of biliary atresia. Progr. Pediatr Surg., 10: 151 (1977).

7. Cole. R. A., Danks, D. M., and Campbell, P. E.: Hepatitis virus in neonatal liver disease. Lancet, $I: 1368$ (1965).

8. Danks, D. M.: Discussion on pathology of the bile retention syndrome. Postgrad. Med. J., 50: 347 (1974).

9. Danks, D. M., and Bodian, M.: A genetic study of neonatal obstructive jaundice.
Arch. Dis. Child., 38: 378 (1963)

10. Danks. D. M.. Campbeli, P. E.. and Jack, I.. Rodgers, J.. and Smith, A. L. Studies of the aetiology of neonatal hepatitis and biliary atresia. Arch. Dis Child.. 52: 360 (1977).

11. Heathcote, J.. Deodhar, K. P., Scheuer, P. J., and Sherlock. S.: Intrahepatic cholestasis in childhood. N. Engl. J. Med.. 295: 801 (1976).

12. Holder. T. M.: Atresia of the extrahepatic bile ducts. Am. J. Surg. 107: 458 (1964).

13. Holder. T. M., and Ashcroft, K. W.: Effects of bile duct ligation and inflammation in the føetus. J. Pediat. Surg., 2: 35 (1967).

14. Hopkins, N. K.: Congenital absence of the common duct. J. Lancet. 61: 90 (1941)

15. Kasai, M.: Treatment of biliary atresia with special reference to hepatic portoen terostomy and its modifications. Progr. Pediatr. Surg., 6: 5 (1974)

16. Kimura, S.: The early diagnosis of biliary atresia. Progr. Pediatr. Surg., 6: 91 (1974).

17. Krauss, A N . Familial extrahepatic biliary atresia. J. Pediatr. 65: 933 (1964)

18. Landing, B. H.: Considerations of the pathogenesis of neonatal hepatitis, biliary atresia and choledochal cyst the concept of infantile obstructive cholangiopathy. Progr. Pediatr. Surg., 6: 113 (1974).

19. Lilly, J. R.: Surgical jaundice in infancy. Ann. Surg., 186: 549 (1977).

20. Miyano. T., Suruga, K., Tsuchiya, H., and Suda, K.: A histopathological study of the remnant of extrahepatic bile duct in so-called uncorrectable biliary atresia. J. Pediatr. Surg., 12: 19 (1977).

21. Morgan. W. W., Rosenkrantz. J. G., and Hill. R. B.: Hepatic artery interruption in the foetus an attempt to simulate biliary atresia. J. Pediat. Surg., $I: 342$ (1966).

22. Myers, R. L., Baggenstoss, A. H.. Logan, G. B., Hollenbeck, G. A., and Froggatt. P.: Congenital atresia of the extrahepatic biliary tract. A Clinical and Pathologic Study. Pediatrics. I8: 767 (1956)

23. Nevin, N. C., Bell, M., Frazer, J. L. et al.: Congenital extrahepatic biliary atresia in two brothers. J. Med. Genet.. 6: 379 (1969).

24. Pickett, L. K.: The liver and biliary tract. In: W. T. Mustard, M. M. Ravitch, W H. Snyder, K. H. Welch, C. D. Benson: Paediatric Surgery. pp. 732-740 (Year Book Medical Publishers, Chicago, 1969).

25. Pickett. L. K., and Briggs, H. C.: Biliary obstruction secondary to hepatic vascular ligation in the fetal sheep. J. Pediat. Surg.. 4: 95 (1969).

26. Poley, J. R.. Smith, E. I., Boon, D. J., Bhatia, M., Smith, C. W., and Thompson J. B.: Lipoprotein $X$ and the double ${ }^{131} I$ rose bengal test in the diagnosis of prolonged infantile jaundice. J. Pediatr. Surg., 7: 660 (1972).

27. Rolleston, H. D., and Hayne, L. B.: A case of congenital hepatic cirrhosis with obliterative cholangitis (congenital obliteration of the bile ducts). Br. Med. J., l: 758 (1901). 
28. Rumler, W.: Uber die Kongenitale Gallenwegsatresia zum familiaren Vorkammen und zum Genese dieser Fehlbildung. Arch. Kinderheilkd., 164: 238 (1961).

29. Schaffner, F., and Popper, H.: Morphologic studies in neonatal cholestasis with emphasis on giant cells. Ann. N. Y. Acad. Sci., 111: 358 (1963).

30. Schweizer, P.: Modell einer extrahepatischen Gallengangsatresia. Z. Kinderchir. Grenzgeb.. 15: 90 (1974).

31. Shim. W. K. T., Kasai, M., and Spence, M. A.: Racial influence of the incidence of biliary atresia. Progr. Pediatr. Surg., 6: 53 (1974).

32. Spitz, L.: Experimental production of cystic dilatation of the common bile duct in neonatal lambs. J. Pediatr. Surg.. 12: 39 (1977).

33. Spitz. L.: An investigation into the etiology. pathogenesis, and treatment of cystic dilatation of the common bile duct. (Ph.D. Thesis. University of the Witwa tersrand, 1979).

34. Stokes, J., Wolman, J. J.. Blanchard, M. C., Farquhar, J. D.: Viral hepatitis in

Copyright $(1) 1980$ International Pediatric Research Foundation, Inc. $0031-3998 / 80 / 1405-0740 \$ 02.00 / 0$ the newborn: clinical features, epidemiology, and pathology. Am. J. Dis. Child.. 82: 213 (1951)

35. Sweet. L. K.: Congenital malformation of the bile ducts: a report of 3 cases in one family. J. Pediatr.. I: 496 (1932).

36. Thomson, J.: On congenital obliteration of the bile ducts. Edinb. Med. J., 37: 523 (1891)

37. Whitten, W. W., and Adie, G. C.: Congenital biliary atresia. J. Pediatr., 40: 539 (1952).

38. YIppo, A.: Zwei Falle von Kongenitalen Gallengansverschluss, Fett-und-Bilirubin-Staffwechselversuche bei einem derselken. Z. Kinderheilkd.. 9: 319 (1913)

39. Requests for reprints should be addressed to: Lewis Spitz. Department of Pediatric Surgery. Institute of Child Health. 30 Guilford Street. London WCIN IEH. England.

40. Received for publication July 16, 1979

41. Accepted for publication August 30, 1979 